\title{
Microwave Assisted Synthesis of some New Chromene Derivatives
}

\author{
Shaymaa K. Younis \\ Department of Chemistry \\ College of Science \\ Mosul University
}

Email: shaymaa_chemistry@yahoo.com

(Received 4 / 5 / 2009 ; Accepted 7 / 12 / 2009)

\begin{abstract}
An efficient synthesis of some new 4-(benzo [d] -1,3-dioxo-5-yl)-[2,3-c]-N-aryl pyrolo-1,3-dione-3,4,5,6-tetrahydro-2H-benzo[h] chromene derivatives (4a-h) via DielsAlder reaction of 2-piperonylidene-1- tetralone (1) and N- aryl maleimides (3a-h) under microwave irradiation was described.

The yield have been improved ( $84-92 \%$ ) and the reaction time reduced from hours to few minutes through the use of dichloromethane as solvent and aluminum chloride as catalyst.

All prepared compounds were confirmed by the available physical and spectral methods.
\end{abstract}

Key words : $2 \mathrm{H}$ - chromene derivatives, microwave irradiation, Diels-Alder reaction .

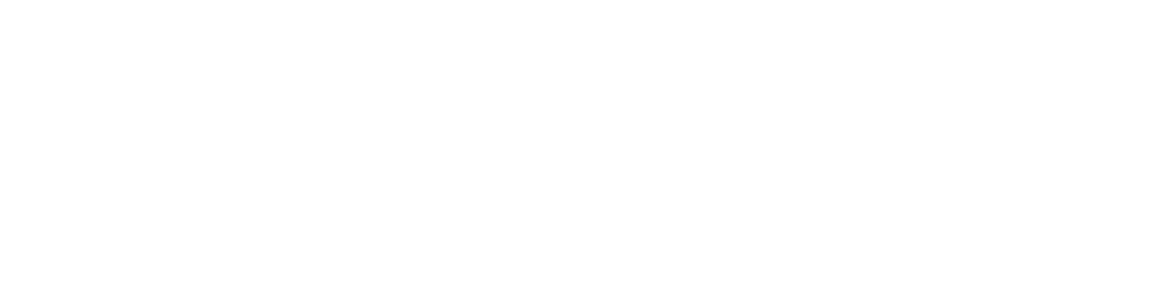

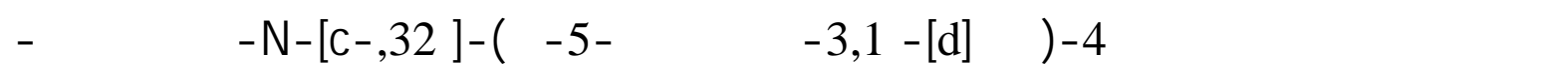

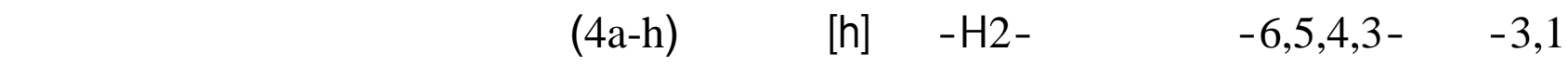

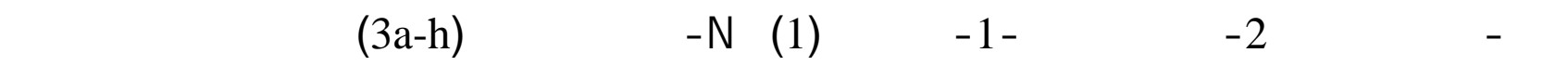

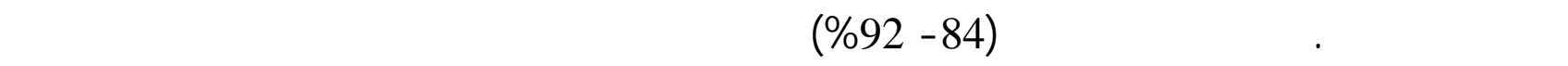

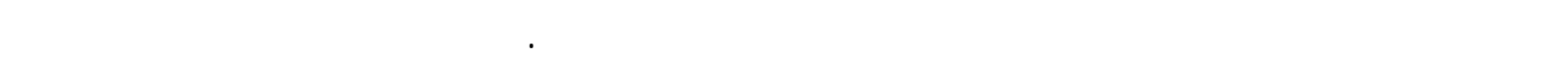
بليستخدل الطرق الفيزياوية و الطيفية المتوفرة.

الكاملت المفتلحية: - مركبك 2 - هيدروكرومين , ققنية التشعبع بالموجلت الدقيقة , قفاعل ديلز - الدر . 